\section{Impact of Seed Treatments on Crop Stand Establishment}

\author{
Mark A. Bennett ${ }^{1}$, \\ Vincent A. Fritz, and \\ Nancy W. Callan ${ }^{3}$
}

Additional index words. seed priming, seed germination, biopriming

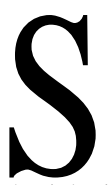

eeds of field-sown crops often are exposed to adverse environmental conditions during germination, emergence, and seedling development. Several environmental and seed physiological factors interact with these growth stages and contribute to the relative success of crop production. Advances in seed priming, coating, pathogen control, and various combinations of other presowing seed treatments show promise for improvement of crop stand establishment.

The need for reliable and uniform crop establishment in horticultural production systems is well recognized (Herner, 1986; Heydecker and Coolbear, 1977; Gray, 1978; Matthewsand Powell, 1986). After the many steps involved in seed production, harvesting, milling, and storage, the ultimate indicator of a seedlot's quality is its performance upon sowing in the field or greenhouse. Factors that limit stand establishment includesoil crusting, poor seed/soil contact, excessively high or low temperatures, seed-borne/soil-borne pathogens, and deficient or excessive soil moisture. In the face of these environmental stresses, achieving acceptable seed germination and emergence (and transplant survival) is no small task in stand establishment. This paper discusses the scope and impact of several types of seed treatments that can improve crop establishment.

Journal Article no. 115-91. The Ohio Agricultural Research and Development Center, The Ohio State University

'Assistant Professor, Department of Horticulture, The Ohio State University, Columbus, OH 43210.

${ }^{2}$ Associate Professor, Southern Experiment Station, University of Minnesota, Waseca, MN 56093.

${ }^{3}$ Associate Professor, W. Agr. Research Center, Montana State University, Corvallis, MT 59828.
These discussions concern only vigorous, nondormant, orthodox, and disease-free seed, although some treatments may possibly benefit medium-quality seed.

\section{Seed quality and stand establishment}

Factors affecting seed quality include 1) pericarp damage, 2) maturity of seed at harvest, 3) exposure to low temperatures or frost during maturation, 4) drying rate, 5) age of seed, and 6) genetically inferior endosperm and embryo (Andrew, 1982; Tatum, 1954; Wiebe, 1989). Imbibitional chilling injury has been identified as a major contributing factor to poor stand establishment in cold soils, particularly in those crops having tropical or subtropical origins (DeVos et al., 1981; Lyons, 1973). A nonregulated rate of initial imbibition due to one or more of the factors listed above has been associated with cell membrane disruption during the transition from the "hexagonal II phase" to the lipid bilayer phase (Herner, 1986; Simon, 1974; Simon and Harun, 1972). This type of imbibition leads to solute leakage into the surrounding medium, which not onlyweakens the vigor of the seed, but also creates a favorable environment for soil pathogen attack (Short and Lacy, 1976; Simon and Wiebe, 1975). The greater and more rapid the leakage, the more rapidly the seed deteriorates. If initial seed moisturecontent is increased before imbibition, the rate of germination and seedling emergence can be improved under cold-soil conditions (Cal and Obendorf, 1972; Obendorf and Hobbs, 1970; Pollock et al. 1969).

\section{Seed priming and other presowing imbibition treatments}

Several investigators have explored the use of seed priming treatments in an attempt to better regulate the rate of initial imbibition to allow for orderly membrane phase transition. Generally seed priming is composed of a "controlled" moisturization period that does not allow radicle emergence followed by a dry-down period. This treatment promotes early germinative metabolic processes that result in a rapid and uniform emergence rate in the field. The use of sugars, salts, polyethylene glycol, or mannitol to create soaking solutions with osmotic potentials that provide control of initial imbibition rates has been successful (Bodsworth and Bewley, 1981; Ells, 1963; Powell and Matthews, 1978; Vertucci and Leopold, 1983). This process, called priming or osmoconditioning, has been more consistently beneficial on smallseeded crops (Bodsworth and Bewley, 1981) while having mixed results on large-seeded crops (Bennett and Waters, Jr., 1987a, 1987b). Osmoconditioning differs from a moisturization technique called "hardening," which allows normal imbibition and is followed by a dry-down period. This is done with varying numbers of wetdry cycles (Hegarty, 1970). Another priming technique using media with appropriate matric potentials is called solid matrix priming, in which a solid medium is used as the water delivery system (Kubik et al., 1988). Vermiculite is commonly used without (Bennett and Waters, 1987a) or with a slurry containing the osmotic material (Taylor et al., 1988). Other substrates can also be used provided they are 1) nontoxic, 2) have high waterholding capacity, 3) remain friable at different moisture contents, and 4) are easily separated from the seeds after priming.

The utility of seed priming for improving crop establishment is well established. Reviews document the improvements in germination and emergence for $>30$ agronomic and horticultural species, and the list is likely to increase (Bradford, 1986; Heydecker and Coolbear, 1977). Priming technology is now at the stage for developing systems to achieve specific objectives, although the exact physiological mechanisms involved in priming need more study (Akers et al., 1985; Basra et al., 1989). Priming influences both theoptimum and cardinal temperature ranges for germination (Bradford, 1986; Ellis and Butcher, 1988; GarciaHuidobro et al., 1982). In priming studies with carrot (Daucus carota L.), improvements in seed germination were marked at $35 \mathrm{C}$, with $74 \%$ vs. $11 \%$ germination for primed and control seed lots, respectively. Priming was also effective in overcoming lettuce thermodormancy and improving stand establishment in hot weather (Valdes et al., 1985).

Priming can increase crop uniformity by reducing the time needed for stand establishment and minimizing the exposure to soil crusting, unfavorable temperatures and soil-borne diseases (Alvarado et al., 1987). When combined with beneficial microorganisms, primed beet (Beta vulgaris L.) seeds are significantly less susceptible to stand losses from disease (Taylor et al., 1985). Although seed priming has not proved useful for tabasco pepper (Capsicum frutescens L.) field stand establishment (Sundstrom et al., 1987) primed muskmelon (Cucumis melo L.) seed provided more rapid emergence or increased final emergence in five of seven field trials (Bradford et al., 1988).

Otherseed treatmentsthat involve imbibition before planting include: presoaking, moistening, low-moisture-content-germinated (LMCG) seed, and matriconditioning (Bennett et al., 1988; FinchSavage, 1988; Heydecker and Coolbear, 1977; Khan et al., 1990). Irrigation delays of 1 to 2 days after planting moistened seed had no detrimental effects on sweet corn (Zea mays L.) emergence or seedling growth, but delaying irrigation until 4 days after sowing increased time to emergence, silking, and harvest (Waters et al., 1990). More work, which may point to a role for preplant irrigation, is needed in this area (Schuler, 1978). Use of LMCG brassica seed combines selection on the basis of an emerged radicle, with easier handling 
and sowing, since the seed is dried to a moisture content $<20 \%$.

The use of osmotic soaking media under vacuum conditions during priming may improve the degree of uniformity of imbibition, particularly in seeds having a pericarp that varies in thickness. Poor pericarp integrity, small seed size, low carbohydrate reserve, and high sugar levels in the embryo all contribute to very low germination and seedling emergence of sweet corn in cold soils (Schmidt and Tracy, 1988; Styer and Cantliffe, 1983a, 1983b; Wann, 1980). A rapid, nonregulated rate of imbibition has been observed in the $s h$ sweet corn seed (Fritz and Hebel, 1990).

To test the influence of vacuum osmoconditioning, three 200-seed replications of a poorvigor, high-sugar $\left(s h_{2}\right)$ sweet corn cultivar, How Sweet It Is, and a normal sugary (su) cultivar, Jubilee, were treated (V.A. Fritz et al., unpublished). The osmotic media selected for the study were $\mathrm{dH}{ }_{2} \mathrm{O}, \mathrm{Ca}\left(\mathrm{NO}_{3}\right)_{2}$ and $\mathrm{Mg}\left(\mathrm{NO}_{3}\right)_{2}$. Seeds wereplaced in a $200-\mathrm{ml}$ beaker fitted with a fine-mesh screen to prevent seeds from floating to the surface of the osmotic media. The beaker and seeds then were placed into a vacuum vessel (Advanced Growth Systems, Vancouver, B.C.) that contained $800 \mathrm{ml}$ of one of the solutions having an osmotic potential of $-0.5 \mathrm{MPa}$. The entire vessel was submerged in a recirculating water bath at $25 \pm 1 \mathrm{C}$. Before submerging the seeds in the vacuum vessel the temperature of the osmotic media and water bath were equilibrated. Once submerged, a vacuum $(-90 \mathrm{kPa})$ was created inside the vessel and maintained for $10 \mathrm{~min}$. The vacuum period was followed immediately by $10 \mathrm{~min}$ of low pressure $(35 \mathrm{kPa})$. After a total 20-min priming treatment the seeds were removed and allowed to air-dry at $25 \mathrm{C}$ for 4 $\mathrm{h}$ and tested for germination and seed vigor.

The use of different osmotic media had no significant effect on germination or seedling vigor (data not shown). Normal seedling germination and the number of nongerminated seeds showed significant cultivar $x$ vacuum interactions when averaged across all osmotic media (Table 1). The vacuum osmoconditioning treatment had deleterious effects on 'How Sweet It Is', while 'Jubilee' was not affected.

A field study was also conducted with 'How Sweet It Is' using the vacuum osmoconditioning treatments identical to those described earlier. Four replications of 200 seeds each were primed and planted on 1 June at the North Central Ex- periment Station in Grand Rapids, Minn. Rate of emergence was recorded beginning 10 days after planting and continuing for 10 days. Seeds treated with $\mathrm{Ca}\left(\mathrm{NO}_{3}\right)_{2}$ showed the most positive response when treated in theabsence of a vacuum; however emergence differences were not significant (data not shown). Vacuum osmoconditioning as a main effect significantly decreased final seedling emergence of 'How Sweet It Is' (41\% vs. 31\% final emergence without and with vacuum, respectively). The use of vacuum osmoconditioning as a means to enhance sweet corn germination and seedling emergence does not appear to be beneficial at this time. However, these initial investigations provide a useful base for continuing investigations that will modify the severity of the procedure.

Uniform and rapid seedling establishment is desirable for several reasons, even though some crops (e.g., soybeans, muskmelon) will compensate for early stand losses (Bradford et al., 1988; Torii et al., 1987). Nonuniform crop emergence results in plants of variable size and competitive ability. Subsequent management practices (nutrient and herbicide applications, use of plant growth regulators, etc.) may be less effective on fields with staggered emergence. If stand establishment is poor, yields and quality of once-over machineharvested crops will be poor.

Seed treatments to improve crop stands need to fit the many variables of production agriculture. The ability of seed treatments to withstand storage, produce healthy seedlings in a variety of seedbeds and soil types, and interact with crop protection agents is critically important. Storage research with primed or other presowing seed treatments of tomato (Lycopersicon esculentum Mill.), sweet corn, pepper (C. annuum L.), and other crops is encouraging (Alvarado and Bradford, 1988; Ghate and Chinnan, 1987; Waters et al., 1990). Interactions among seed vigor classes (native or enhanced) and herbicide programs have been studied in sweet corn and tomato (Argerich et al., 1990 ;Bennett and Gorski, 1989). The influence of seed treatments and seed vigor is especially significant under stressful conditions that favor crop injury (DeVos et al., 1981; Schultheis et al., 1988).

Tillage systems also influence the field performance of seed treatments. Increased use of reduced tillage and higher levels of previous crop residues will place more demand on seed treatments that deliver vigorous emergence and growth. Crop residues presentchallenges in overcoming reduced soil temperatures, achieving uniform seed placement, and ensuring good seed-soil contact.

Ghate and Phatak (1982) reported pepper and tomato seed treatment results that were different for loamy sand than for sandy soil. Consideration of these and other variables may lead to more coordination of seed enhancement treatments under field or greenhouse conditions so that the full potential of a seed lot can be expressed (Bradford, 1986). It is encouraging that the greatest seed treatment benefits often are seen for earlier plantings, when soils typically are cool and wet (Bennett and Waters, 1987a; Ghate and Phatak, 1982; Herner, 1986).

Seed coatings. Seed coatings or pellets can also affect stand establishment. Coatings play a role in regulating water uptake, which may be critical if testa or pericarp integrity is poor (Powell, 1979; Styer and Cantliffe, 1983b; Tully et al., 1981). Hydrophilic compounds containing hydrolyzed starch have been tested with some success as seed coatings for sweet corn, with the best results obtained in soils near field capacity (Baxter and Waters, Jr., 1986a, 1986b). Coatings or pellets also can be used as carriers for nutritional, hormonal, osmotic, or crop protection treatments (Khan and Taylor, 1986). The primary role for coatings was initially to improve singulation or placement of seed. With the increasing use of high-priced hybrid seed and the availability of vacuum seeding equipment, seed coatings are very useful in horticultural crop establishment (Bazin et al., 1989).

Biological seed treatment. A primary cause of seedling stand reduction in many crops is pre-emergence damping-off or seed-rotting induced by soil-borne pathogens. Damping-off may be particularly severe when poor-quality seed is sown under adverse soil temperature and moisture conditions (Harman and Stasz, 1986; Herner, 1986). Frequently encountered seedrotting pathogens include pythum spp., Rhizoctonia solani Kuhn, and Fusarium spp. (Harman and Stasz, 1986).

Seed treatment is the most efficient delivery method for chemicals or biological control agents that will protect seeds from soil-borne pathogens. A number of microorganisms have been selected for use in biological seed treatments for control of damping-off. A comprehensive review of biological seed treatments is not within the scope of this paper; rather, we will attempt to provide an overview of the range of biocontrol agents currently under study for use in seed treatments and to examine methods by which more consistent biological seed protection may be achieved. The reader is referred to discussions of biological seed treatments by Cook (1986) and Taylor and Harman (1990).

Biological seed treatment has generally not been considered a dependable option for seed protection. The nature and requirements of living microorganisms are often responsible for variability 
in biological seed protection. Failure of the biocontrol agent to become active on the seed rapidly enough to control the pathogen may account for inconsistent performance. Many fungal biocontrol agents are applied as conidia or other resting spores. While these survival structures offer resistance to desiccation, they must germinate before interaction with the pathogen is possible. Sporangia of $P$. ultimum began to germinate within 3 to $4 \mathrm{~h}$ in response to exudates from bean (Phaseolus vulgaris L.) seeds (Stanghellini and Hancock, 1971) and sweet corn seeds were infected by $P$. ultimumas quickly as $8 \mathrm{~h}$ after planting (N.W. Callan, unpublished data), so a very rapid response is needed. In addition, the bioprotectant may not be present on the seed in adequate numbers, or may not persist in the spermoplane or spermosphere long enough to protect the germinating seed. Of practical consideration is the perishability of the biological control formulation. Adverse storage conditions may further decrease effectiveness of a seed treatment.

Several genera of fungi have been evaluated for use as seed bioprotectants. While species of Trichoderma and Gliocladium have been among the most studied (Hadar et al., 1984; Harman and Taylor, 1988; Harman et al., 1989; Lifshitz et al., 1986) other fungal biocontrol agents have also increased seedling stands in the greenhouse or field. Seed treatments using oospores of the mycoparasite $P$. oligandrum protected sugar beet seed (Walther and Gindrat, 1987a; Martin and Hancock, 1987) and chickpeas (Cicer arietinum L.) (Trapero-Casas et al., 1990) from damping-off caused by $P$. ultimum, while $P$. nunn was effective as a protectant against $P$. ultimum on cucumber (Cucumis sativus L.) seed (Paulitz and Baker, 1987). Penicillium oxalicum increased emergence of chickpeas (Kaiser et al, 1989; TraperoCasas et al., 1990) and peas (Pisum sativum L.) (Windels and Kommedahl, 1982) in soil infested with several Pythium spp. Nonpathogenic Rhizoctonia spp. protected sugar beet seeds against P. ultimum, and may have potential against $R$. solani (Walther and Gindrat, 1987b). Preemergence damping-off was controlled by Laetisaria arvalis when used as a seed treatment on table beet (Hoch and Abawi, 1979).

Seed treatments using saprophytic bacteria have also demonstrated potential for increasing seedling stand. Bacteria normally require less time for activation, but must either form resistant structures, as do Bacillus spp., or be otherwise able to maintain an effective population on the seed until planting in order to provide protection. Enterobacter cloacae increased emergence of several crops when planted in soil infested with Pythium spp. (Hadar et al., 1983; Harman and Taylor, 1988; Nelson, 1988; Taylor et al., 1985). Other bacterial antagonists include Erwinia herbicola, used to protect cotton (Gossypium hirsutum L.) seed from Pythium spp. (Nelson, 1988), and Bacillus subtilis (Merriman et al., 1975).
Fluorescent pseudomonads comprise a group of bacteria that have been well used for control of seed-rotting pathogens. Pseudomonas spp. have been used on seeds of various crops for control of diseases caused by Pythium spp. (Callan et al., 1990; Howell and Stipanovic, 1980; Kaiser et al., 1989; Loper, 1988; Osburn et al., 1989) and R. solani (Howell and Stipanovic, 1979). Separate antibiotics responsible for antagonism toward $R$. solani (Howell and Stipanovic, 1979) and $P$. ultimum (Howell and Stipanovic, 1980) were characterized from a single strain of Pseudomonas fluorescens. Seed protection from damping-off was achieved by treatment with either antibiotics or the $P$. fluorescens strain.

Baker and Scher (1987) and Taylor and Harman (1990) discussed methods that may enhance the effectiveness of biological control agents. Two methods appropriate to this discussion include: 1) manipulation of the host to be protected and 2) manipulation of theenvironment in which the biocontrol agent must operate. Physiological seed treatment in the presence of a biocontrol agent uses both of these strategies and can result in more consistent seed protection. Because failure of seedlings to emerge may involve both pathogen attack and physiological problems, combining biological and physiological seed treatments appears to be a logical development.

Manipulation of the host (in this case the seed to be protected) may involve several of the pregermination or priming procedures discussed in the previous section. Many seeds pass through a period of disease susceptibility immediately following sowing, after which they become more resistant as germination proceeds. Allowing pea seeds to germinate for 16 to $40 \mathrm{~h}$ before exposure to the pathogen markedly decreased their susceptibility to infection by P. ultimum (Stasz et al., 1980). Physiological disorders affecting seeds may further compromise the effectiveness of biological seed treatments. Seeds of some species are subject to imbibitional chilling injury, in which membranes of dry seeds are injured when the seed takes up moisture rapidly under low temperatures (Herner, 1986). Such seeds suffer increased susceptibility to infection by soil-borne pathogens.

The environment favoring activity of the bioprotectant may differ from that favoring infection by the pathogen and quite often differs from the environment in which the seed is planted. Soil temperature, moisture, and reaction may not permit rapid germination and establishment of a fungal bioprotectant such as Trichoderma spp. when applied to seed as conidia. However, conditions may be adjusted during the priming process to allow the bioprotectant to colonize the seed before planting. When cucumber or tomato seeds were treated with Trichoderma spp. or $E$. cloacae and primed in a solid matrix, the organic carrier could be selected to suit the very different requirements for growth of these two biocontrol agents. The addition of solid matrix priming to biological seed treatments improved the reliability of protection from Pythium preemergence damping-off (Harman and Taylor, 1988; Harman et al., 1989).

Pregermination or osmoconditioning may result in a situation in which biological control contributes to the effectiveness of the seed treatment. When cucumber and pea seeds were pregerminated in aerated water, bacteria present on the seeds, predominantly E. cloacae, proliferated in the water and colonized the seeds, reaching a level of $10^{7} \mathrm{cfu} / \mathrm{seed}$. These seeds were protected from $P$. ultimum preemergence damping-off, while little or no protection was afforded seeds germinated aseptically (Hadar et al., 1983). Table beets were also protected from damping-off by pregermination or osmoconditioning in the presence of bacteria, but leaching or osmoconditioning was ineffective without high bacterial populations on the seed (Taylor et al., 1985). Osburn and Schroth (1988) found that osmoconditioning seeds with antibiotics to inhibit bacterial growth somewhat increased seedling emergence in Pythium-infested soil, but the influence of bacteria was highly variable. Presumably, the bacterial strainscolonizing seeds during osmoconditioning would have an influence on the effectiveness of the treatment. Hadar et al. (1983) treated pea, beet, and cucumber seeds with either the total bacterial population from pregerminated seeds or a selected strain of $E$. cloacae, and found that Pythium spp. seed rot was reduced.

The biopriming procedure described by Callan et al. (1990) for biological control of Pythium preemergence damping-off of $s h_{2}$ sweet corn integrated imbibition at an optimal temperature with protection by a biocontrol agent. Imbibitional chilling injury was prevented while the bioprotectant became established on the seed in high numbers. Biopriming combined the moisturizing process of Bennett and Waters (1987a) with treatment with $P$. fluorescens AB254, a naturally occurring bacterial strain that was isolated from western Montana soil. While seed treatment, or bacterization, with $P$. fluorescens $\mathrm{AB} 254$ was frequently sufficient to protect sweet corn seeds from Pythium preemergence damping-off, biopriming resulted in the most dependable seed protection. With biopriming, sweet corn seedling emergence equivalent to that with metalaxyl treatment was obtained consistently in the field (Bennett et al., 1991).

Both acceleration of emergence and treatment with $P$. fluorescens AB254 were clearly involved in seed protection by biopriming. By addressing both the physiological and pathological problems of seedling emergence, biopriming results in emergence that is more consistent and more complete. Selecting strains of biocontrol agents with greater specificity against key soilborne disease will further improve seedling establishment of horticultural crops. 


\section{Literature Cited}

Akers, S. W. J. Brede, and J.J. Bates. 1985 Why some vegetable seeds cannot be primed in aerated solutions. HortScience 20:549. (Abstr.)

Alvarado, A. D., K.J. Bradford, and J.D. Hewitt. 1987. Osmotic priming of tomato seeds; effects on germination, field emergence, seedling growth, and fruit yield. J. Amer. Soc. Hort. Sci. 112:427-432.

Alvarado, A.D., and K.J. Bradford 1988. Priming and storage of tomato (Lycopersicon esculentum) seeds. II. Influence of a second treatment after storage on germination and field emergence. Seed Sci. \& Technol. 16:613623

Andrew, R.H. 1982. Factors influencing early seedling vigor of shrunken-2 maize. Crop Sci. 22:263-266.

Argerich, C.A., K.J. Bradford, and F. M. Ashton. 1990. Influence of seed vigor and pre-plant herbicides on emergence, growth, and yield of tomato. HortScience 25:288-291.

Baker, R. and F.M. Scher. 1987 Enhancing the activity of biological control agents. In: I. Chet (ed.). Offprints from innovative approaches to plant disease control. Wiley, New York.

Basra, A.S., R. Dhillon, and C.P. Malik. 1989. Influence of seed pre-treatments with plant growth regulators on metabolic alterations of germinating maize embryos under stressing temperature regimes. Ann. Bot. 64:3741.

Baxter, L. and L. Waters, Jr., 1986a. Effect of a hydrophilic polymer seed coating on the field performance of sweet corn and cowpea. J. Amer. Soc. Hort. Sci. 111:31-34.

Baxter, L. and L. Waters., Jr. 1986b. Effect of a hydrophilic polymer seed coating on the imbibition, respiration and germination of sweet corn at four matric potentials. J. Amer. Soc. Hort. Sci. 111:517-520.

Bazin, M., J.F. Morin, J.P Vergneau. 1989. New technologies in seed protection. Acta Hort. 253:268-269.

Bennett, M.A.. N.W. Callan, and V.A. Fritz. 1991. Seed treatments for disease control. HortTechnology 1:8487.

Bennett, M.A., and S.P Gorski. 1989. Response of sweet corn (Zea mays) endosperm mutants to chloracetamide and thiocarbamate herbicides. Weed Technol. 3:475478.

Bennett, M.A., L. Waters, Jr., and J. H. Curme. 1988. Kernel maturity, seed size, and seed hydration effects on the seed quality of a sweet corn inbred. J. Amer. Soc. Hort. Sci. 113:348-353.

Bennett, M.A. and L. Waters, Jr. 1987a. Seed hydration treatments for improved sweet corn germination and stand establishment. J. Amer. Soc. Hort. Sci. 112:4549.

Bennett, M.A. and L. Waters, Jr. 1987b. Germinationand emergence of high-sugar sweet corn is improved by presowing hydration of seed. HortScience 22:236-238.

Bodsworth, S. and J.D. Bewley. 1981. Osmotic priming of seeds of crop species with polyethylene glycol as a means of enhancing early and synchronous germination at cool temperatures. Can. J. Bot. 59:672-676.
Bradford, K.J. 1986. Manipulation of seed relations via osmotic priming to improve germination under stress conditions. HortScience 21:1105-1 112.

Bradford, K. J., D. M. May, B. J. Hoyle, Z.S. Skibinski, S. J. Scott, and K.B. Tyler. 1988. Seed and soil treatments to improve emergence of muskmelon from cold or crusted soils. Crop Sci. 28:1001-1005.

Cal, J.P. and R.L. Obendorf. 1972. Imbibitional chilling injury in Zea mays L. altered by initial kernel moistureand maternal parent. Crop Sci. 12:369-373.

Callan, N. W, D.E. Mathre, and J.B. Miller. 1990. Biopriming seed treatment for biological control of Pythium ultimum preemergence damping-off in sh2 sweet corn. Plant Dis. 74:368-372.

Cook, R.J. 1986. Plant health and the sustainability of agriculture, with special reference to disease control by beneficial microorganisms. Biol. Agr. and Hort. 3:211232

De Vos, D.A., R. R. Hill, Jr., R. W. Hepler, and D. L. Garwood. 1981. Inheritance of low temperature sprouting ability in $\mathrm{F}_{1}$ tomato crosses. J. Amer. Soc. Hort. Sci. 106:352-355.

Ellis, R.H. and P.D. Butcher. 1988. The effects of priming and 'natural' differences in quality amongst onion seed lots on the response of the rate of germination to temperature and the identification of the characteristics under genotypic control. J. Expt. Bot. 39:935-950.

Ells, J.E. 1963. The influence of treating tomato seed with nutrient solutions on emergence rate and seedling growth. Proc. Amer. Soc. Hort. Sci. 83:684-687.

Finch-Savage, W.E. 1988. A comparison of Brussels sprout seedling establishment from ungerminated and low-moisture-content germinated seeds. Ann. Applied Biol. 113:425-429.

Fritz, VA. and J.B. Hebel. 1990. The effects of vacuum moisturization on germination and seedling vigor of $\mathrm{sh}_{2}$ sweetcorn. Proc. Natl. Symp. on Stand Establishmentfor Hort. Crops. p. 63-70

Garcia-Huidobro, J., J. L. Monteith, and G.R. Squire. 1982. Time, temperature and germination of pearl millet (Pennisetum typhoides) S. \& H.). II. Alternating temperature. J. Expt. Bot. 33:297-302.

Ghate, S.R. and M.S. Chinnan. 1987. Storage of germinated tomato and pepper seeds. J. Amer. Soc. Hort. Sci. 112:645-651.

Ghate, S. R. and S.C. Phatak. 1982. Performance of tomato and pepper seeds germinated before planting. J. Amer. Soc. Hort. Sci. 107:908-911

Gray, D. 1978. The role of seedling establishment in precision cropping. Acta Hort. 83:309-315.

Hadar, Y., G.E. Harman, and A.G. Taylor. 1984. Evaluation of Trichoderma koningii and T. harzianum from New York soils for biological control of seed rotcaused by Pythium spp. Phytopathology 74:106-110.

Hadar, Y., G.E. Harman, A.G. Taylor, and J. M. Norton. 1983. Effects of pregermination of pea and cucumber seeds and of seed treatmentwith Enterobacter cloacae on rots caused by pythium spp. Phytopathology 73:13221325.
Harman, G.E. A.G. Taylor, and T.E. Stasz, 1989. Combining effective strains of Trichoderma harzianum and solid matrix priming to improve biological seed treatments Plant Dis. 73:631-637.

Harman, G.E. and A.G. Taylor. 1988. Improved seedling performance by integration of biological control agents at favorable $\mathrm{pH}$ levels with solid matrix priming. Phytopathology 78:520-525.

Harman, G.E. and T.E. Stasz, 1986. Influence of seed quality on soil microbes and seed rots. In: S.H. West (ed.) Physiological-pathological interactions affecting seed deterioration. Crop Sci. Soc. of Amer., Madison, Wis.

Herner, R.C. 1986. Germination under cold soil conditions. HortScience 21:1118-1122.

Hegarty, T.W. 1970. The possibility of increasing field establishment by seed hardening. Hort Res. 10:59-64.

Heydecker, W. and P. Coolbear. 1977 Seed treatment for improved performance-survey and attempted prognosis. Seed Sci. \& Technol. 5:353-425.

Hoch, H.C. and G.S. Abawi. 1979. Biological control of Pythium root rot of table beet with Corticum sp. Phytopathology 69:417-419.

Howell, C.R. and R.D. Stipanovic. 1979. Control of Rhizoctonia solani on cotton seedlingswithPseudomonas fluorescens and with an antibiotic produced by the bacterium. Phytopathology 69:480-482.

Howell, C. R. and R. D. Stipanovic. 1980. Suppression of Pythium ultimum-induced damping-off of cotton seedlings by Pseudomonas fluorescens and its antibiotic, pyoluteorin. Phytopathology 70:712-715.

Kaiser, W.J., R.M. Hannan, and D.M. Weller. 1989 Biological control of seed rot and preemergence dampingoff of chickpea with fluorescent pseudomonads. Soil Biol. Biochem. 21:269-273.

Khan, A.A.. H. Miura, J. Prusinski, and S. Ilyas. 1990. Matriconditioning of seeds to improveemergence. Proc. Natl. Symp. on Stand Establishment for Hort. Crops, p. $19-40$.

Khan, A.A. and Taylor. 1986. Polyethylene glycol incorporation into table beet seed pellets to improve emergence and yield in wet soil. HortScience 21:987989.

Kubik, K.K., J.A. Eastin, J. D. Eastin, and K. M. Eskridge. 1988. Solid matrix priming of tomato and pepper. Proc. Intl. Conf. on Stand Establishment for Hort. Crops. p. 86-96.

Lifshitz, R., M.T. Windham, and R. Baker. 1986. Mechanism of biological control of preemergence damping-off of pea by seed treatment with Trichoderma spp. Phytopathology 76:720-725.

Loper, J.E 1988. Role of fluorescent siderphore production in biological control of pythium ultimum by a Pseudomonas fluorescens strain. Phytopathology 78:166-172.

Lyons, J.M. 1973. Chilling injury in plants. Annu. Rev. Plant Physiol. 24:445-466.

Martin, F. N. and J.G. Hancock. 1987. The use of pythium oligandrum for biological control of preemergence damping-off caused by $P$. ultimum. Phytopathology 77:1013-1020 
Matthews, S. and A.A. Powell. 1986. Environmental and physiological constraints on field performance of seeds, HortScience 21:1125-1128.

Merriman, P. R., R.D. Price, K.F. Baker, J. F. Kollmorgen, T. Piggott, and E.H. Ridge. 1975. Effect of Bacillus and Streptomyces spp. applied to seed. In: G.W. Bruehl (ed.). Biology and control of soil-borne plant pathogens. American Phytopathological Soc., St. Paul, Minn.

Nelson, E.B. 1988. Biological control of Pythium seed rot and preemergence damping-off of cotton with Enterobacter cloacae and Erwinia herbicola applied as seed treatments. Plant Dis. 72:140-142

Obendorf, R.L. and P.R. Hobbs. 1970. Effect of seed moisture on temperature sensitivity during imbibition of soybean. Crop Sci. 10:563-566.

Osburn, R.M. and M.N. Schroth. 1988. Effect of osmopriming sugar beet seed on exudation and subsequent damping-off caused by Pythium ultimum. Phytopathology 78:1246-1250.

Osburn, R.M., M.N. Schroth, J.G. Hancock, and M. Henderson. 1989. Dynamics of sugar beet colonization by Pythium ultimum and Pseudomonas species: effect on seed rot and damping-off. Phytopathology 79:709716.

Paulitz, T.C. and R. Baker. 1987. Biological control of Pythium damping-off of cucumbers with Pythium nunn: population dynamics and disease suppression. Phytopathology 77:335-340.

Pollock, B.M., E.E. Roos, and J.R. Manalo. 1969. Vigor of garden bean seeds and seedlings influenced by initial seed moisture, substrate oxygen, and imbibition temperature. J Amer. Soc. Hort. Sci. 94:577584.

Powell, A.A. 1979. The influence of testa condition on the imbibition and vigor of pea seeds, J. Expt. Bot. 30:193197.

Powell, A.A. and S. Matthews. 1978. The damaging effect of water on dry pea embryos during imbibition. J. Expt. Bot. 29:1215-1229.

Schmidt, D.H. and W.F. Tracy, 1988. Endosperm type, inbred background and leakage of seed electrolytes during imbibition in sweet corn J. Amer. Soc. Hort. Sci. 113:269-272.
Schuler, K.D. 1978. Reducing vegetable seedling injury from salinity by increasing germination rate with pregermination seed treatments. MS Thesis, Univ. of Florida, Gainesville.

Schultheis, J. R., D. J. Cantiliffe, H. H. Bryan, P. J. Stoffella. 1988. Planting methods to improve stand establishment, uniformity, and earliness to flower in bell pepper, J. Amer. Soc. Hort. Sci. 113:331-335.

Short, G.E. and M.L. Lacy. 1976. Carbohydrate exudation from pea seeds: Effect of cultivar, seed age, seed color, and temperature, and relation to fungal rots. Phytopathology 66:182-187.

Simon E.W. 1974. Phospholipids and plant membrane permeability. New Phytol. 73:377-420.

Simon, E.W. and R. M. Raja Harun. 1972. Leakage during imbibition. J. Expt. Bot. 23:1076-1085.

Simon, E. W. and H.H. Wiebe. 1975. Leakage during imbibition, resistance to damage at low temperature and the water content of peas. New Phytol. 74:407-411,

Stanghellini, M. E. and J.G. Hancock. 1971. Radical extent of the bean spermosphere and its relation to the behavior of Pythium ultimum. Phytopathology 61:165168.

Stasz, T.E., G.E. Harman, and G.A. Marx. 1980. Time and site of infection of resistant and susceptible germinating pea seeds by Pythium ultimum. Phytopathology 70:730 733.

Styer, R.C. and D.J. Cantliffe. 1983a. Relationship between environment during seed development and seed vigor of two endosperm mutants of corn. J. Amer. Soc. Hort. Sci. 108:717-720.

Styer, R.C. and D.J. Cantliffe. 1983b. Changes in seed structure and composition during development and their effects on leakage in two endosperm mutants of sweet corn. J. Amer. Soc. Hort. Sci. 108:721-728.

Sundstrom, F. J., R. B. Reader, and R. L. Edwards. 1987. Effect of seed treatment and planting method on tabasco pepper. J. Amer. Soc. Hort. Sci. 112:641-644.

Tatum, L.A. 1954. Seed permeability of cold test reactions in Zea mays. Agron. J. 46:8-10.

Taylor, A.G. and G.E. Harman. 1990. Concepts and technologies of selected seed treatments. Annu. Rev. Phytopathol. 28:321-339.
Taylor, A.G., D. E. Klein, and T. H. Whitlow. 1988. SMP: Solid matrix priming of seeds. Scientia Hort. 37:1-11.

Taylor, A.G., Y. Hadar, J. M. Norton, A.A. Khan, and G.E. Harman. 1985. Influence of presowing seed treatments of table beet on the susceptibility to damping-off caused by Pythium. J. Amer. Soc. Hort. Sci. 110:516-519.

Torii, K., B.L. Vasilas, S.G. Carmer, and C.A. Smyth. 1987. Growth and yield response of solid-seeded soybean to early season stand reduction. Agron. J. 79:555558.

Trapero-Casas, A., W.J. Kaiser, and D. M. Ingram. 1990. Control of Pythium seed rot and preemergence dampingoff of chickpea in the U.S. Pacific Northwest and Spain, Plant Dis. 74:563-569.

Tully, R.E, M.E. Musgrave, and A.C. Leopold. 1981. The seed coat as a control of imbibitional chilling injury. Crop Sci. 21:312-317.

Valdes, V.M., K.J. Bradford, and K.S. Mayberry. 1985. Alleviation of thermodormancy in coated lettuce seeds by seed priming. HortScience 20:1112-1114.

Vertucci, C. W. and A.C. Leopold. 1983. Dynamics of imbibition by soybean embryos. Plant Physiol. 72:190193.

Walther, D. and D. Gindrat. 1987a. Biological control of Phoma and Pythium damping-off of sugar-beet with Pythium oligandrum. J. Phytopathol. 119:167-174.

Walther, D. and D. Gindrat. 1987b. Antagonism of Rhizoctonia spp. to Pythium oligandrum and damping-off fungi. J. Phytopathol. 119:248-254.

Wann, E.V. 1980. Seed vigor and respiration of maize kernels with different endosperm genotypes. J. Amer. Soc. Hort. Sci. 105:31-34.

Waters, L., Jr.. R.L. Burrows, M.A. Bennett and J. Schoenecker. 1990. Seed moisture and transplant management techniques influence sweet corn stand establishment, growth, development and yield. J. Amer. Soc. Hort. Sci. 115:888-892.

Wiebe, H.J. 1989. Effects of lowtemperature during seed development on the mother plant on bolting of vegetable crops. Acta Hort. 253:25-30.

Windels, C.E. and T. Kommedahl. 1982. Pea cultivar effect on seed treatment with Penicillium oxalicum in the field. Phytopathology 72:541. (Abstr.) 